\title{
Pembangunan Hukum dalam Peningkatan Daya Saing Usaha Mikro, Kecil, dan Menengah di Indonesia Sebelum dan Pasca Kesepakatan Integrasi Ekonomi ASEAN
}

\author{
U Sudjana*
}

DOI: https://doi.org/10.22304/pjih.v4n2.a5

\begin{abstract}
Abstrak
Pembangunan hukum untuk peningkatan daya saing usaha mikro, kecil, dan menengah telah dilakukan sebelum dan pasca berlakunya Masyarakat Ekonomi ASEAN 2015 melalui beberapa peraturan perundang-undangan baik pembaruan hukum maupun pembentukan hukum baru. Namun pembangunan hukum tersebut masih perlu dilakukan terus menerus secara berkesinambungan karena upaya peningkatan daya saing UMKM mempunyai akibat yang luas terhadap bidang-bidang lainnya. Dengan demikian diperlukan harmonisasi dan sinkronisasi baik di antara perundang-undangan terkait lainnya, maupun dalam rangka pelaksanaan MEA 2015, namun tetap memperhatikan kepentingan nasional.
\end{abstract}

Kata kunci: daya saing, kesepakatan, MEA, pembangunan hukum, UMKM.

\section{Legal Development on The Competitiveness Enhancement of Micro, Small, and Medium Enterprise Prior and After the Enactment of ASEAN Economic Community}

\begin{abstract}
The legal development to increase the competitiveness of small and medium micro enterprise has been done prior and after the enactment of ASEAN Economic Community 2015 through some legislation, both in legal reform and the establishment of new law. However, the construction of the law still needs to be done continuously on an ongoing basis to improve the competitiveness of small and medium micro enterprises, since it will affect extensively to other areas. Thus, it requires harmonization and synchronization between legislation related, as well as in the framework of the implementation of the AEC in 2015, while still considering national interests.
\end{abstract}

Keywords: competitiveness, agreement, AEC, legal development, small and medium micro enterprises.

\section{A. Pendahuluan}

Kesepakatan Indonesia untuk merealisasikan gagasan mengenai Association of South East Asian Nations/ASEAN Free Trade Area (AFTA), ASEAN Economic Community atau Masyarakat Ekonomi ASEAN (MEA) serta keikutsertaan Indonesia sebagai anggota World Trade Organization (WTO) dan Asia Pacific Economic

PADJADJARAN Jurnal IImu Hukum Volume 4 Nomor 2 Tahun 2017 [ISSN 2460-1543][e-ISSN 2442-9325]

* Dosen Fakultas Hukum Universitas Padjadjaran, Jl. Dipati Ukur 35 Bandung, sdjana@yahoo.com, S.H, M.Si, Dr. (Universitas Padjadjaran). 
Cooperation (APEC), telah menunjukan keseriusan pemerintah dalam mendukung sistem perekonomian yang bebas/terbuka, dan secara tidak langsung memacu perusahaan-perusahaan di Indonesia untuk lebih meningkatkan daya saingnya, ${ }^{1}$ terutama Usaha Mikro, Kecil, dan Menengah (UMKM).

UMKM merupakan pelaku ekonomi nasional yang mempunyai peran yang sangat penting dalam pembangunan perekonomian dikarenakan kegiatan usahanya mampu memperluas lapangan kerja dan memberikan pelayanan ekonomi secara luas kepada masyarakat. UMKM sebagai salah satu pilar utama ekonomi nasional yang memberikan kontribusi dalam pertumbuhan ekonomi mendominasi lebih dari 95\% struktur perekonomian nasional. Di tengah tuntutan kemampuan bersaing di dalam negeri yang masih dilindungi proteksi pemerintah, UMKM harus mampu menghadapi tantangan berupa persaingan global yang berasal dari berbagai bentuk usaha mendorong integrasi pasar antar negara. Oleh karena itu, UMKM perlu meningkatkan daya saing melalui kesempatan, dukungan, perlindungan hukum, dan pengembangan usaha seluas-luasnya sebagai wujud keberpihakan yang tegas kepada kelompok usaha ekonomi rakyat tersebut, mengingat UMKM memiliki fungsi yang sangat strategis baik secara sosial ekonomi maupun sosial politik. ${ }^{2}$

Berdasarkan hal itu, peran dan potensi UMKM semakin penting bagi pembangunan ekonomi nasional sehingga beralasan untuk meningkatkan daya saing semaksimal mungkin guna meningkatkan kesejahteraan masyarakat sekaligus mendukung pertumbuhan perekonomian daerah. Pemerintah perlu untuk membantu memenuhi kebutuhan dan fasilitas yang diperlukan dalam rangka menghadapi tantangan globalisasi ekonomi yang sarat dengan persaingan bisnis. Globalisasi ekonomi telah mendorong terjadinya berbagai perubahan di dalam sektor perdagangan yang mengindikasikan telah diterapkannya perdagangan bebas, yang dimulai di tahun 2010 melalui ASEAN Plus China Free Trade Area (ACFTA), ${ }^{3}$ kemudian MEA tahun $2015 .{ }^{4}$

1 Y. Sri Susilo, "Strategi Meningkatkan Daya Saing UMKM dalam Menghadapi Implementasi CAFTA dan MEA", Buletin Ekonomi, Vol. 8, No. 2, Agustus 2010, hlm. 70.

2 (1) Fungsi sosial ekonomi, sektor ini antara lain menyediakan barang dan jasa bagi konsumen berdaya beli rendah sampai sedang, menyumbangkan lebih dari sebagian pertumbuhan ekonomi serta kontributif perolehan devisa negara; (2) Fungsi sosial politik, sektor ini juga sangat penting terutama dalam penyerapan tenaga kerja serta upaya pengentasan kemiskinan, karena sifat sebarannya dan keterkaitannya yang erat dengan sektor pertanian juga sangat potensial untuk mendorong kemajuan ekonomi pedesaan.

3 Komitmen ini tidak terlepas dari perkembangan perdagangan antara Association of South East Asian Nations (ASEAN) dan Tiongkok yang makin meningkat dan merupakan inisiatif ekonomi yang penting bagi kedua belah pihak untuk mewujudkan diri sebagai kekuatan ekonomi dunia yang sangat diperhitungkan pada abad ke-21.

4 Masyarakat Ekonomi ASEAN (MEA) berawal pada Konferensi Tingkat Tinggi (KTT) yang dilaksanakan di Kuala Lumpur pada tahun 1997, yaitu para pemimpin ASEAN akhirnya memutuskan untuk melakukan pengubahan ASEAN dengan menjadi suatu kawasan makmur, stabil, dan sangat bersaing dalam perkembangan ekonomi yang berlaku adil dan mengurangi kesenjangan dan kemiskinan sosial ekonomi (ASEAN Vision 2020). Kemudian dilanjutkan pada KTT Bali pada bulan Oktober pada tahun 2003, para pemimpin ASEAN mengeluarkan 
Bahri mengatakan bahwa:

"Penerapan MEA 2015 merupakan bentuk integrasi ekonomi regional. Dengan asumsi, persaingan bebas di kawasan Asia Tenggara akan memicu setiap negara anggota ASEAN melakukan efisiensi yang optimal dan pada akhirnya akan meningkatkan kesejahteraan masyarakat. Apabila mekanisme tersebut berjalan dengan baik, maka semua negara yang terlibat akan memperoleh keuntungan, meski keuntungan tersebut tidak merata sebarannya." 5

Sedangkan Bangun mengatakan bahwa "persaingan bebas di antara negara anggota ASEAN akan semakin ketat. Negara yang memiliki daya saing tinggi akan membuka kesempatan lebih besar untuk dapat menjadi pemenang, dan sebaliknya, negara yang memiliki daya saing rendah semakin tertinggal" ${ }^{6}$

Berdasarkan Global Competitiveness Report 2014-2015 yang disampaikan oleh World Economic Forum (WEF), daya saing Indonesia berada di peringkat ke-34 dari 144 negara atau mengalami peningkatan dibandingkan tahun 2013 di posisi ke-38. Kondisi ini tentu menjadi modal yang positif bagi pemerintah, khususnya menghadapi tantangan ekonomi global yang kian kompetitif. Dengan beberapa perbaikan yang gencar dilakukan pemerintah, tahun 2013 posisi Indonesia kembali melesat ke peringkat 38. ${ }^{7}$ Dicapainya posisi tersebut menjadikan Indonesia kembali diperhitungkan dalam ekonomi dunia, sehingga secara tegas Bank Dunia memasukkan Indonesia ke dalam 10 besar ekonomi dunia berdasarkan metode perhitungan Purchasing Power Party (PPP). ${ }^{8}$

Penentu Daya Saing (Competitiveness Determinants) itu sendiri dapat dipaparkan sebagai berikut: ${ }^{9}$

1) Indeks Persepsi Korupsi (Corruption Perception Index). Indeks ini mengukur tingkat persepsi korupsi di sektor publik di seluruh negara melalui skala yang

pernyataan bahwa MEA akan menjadi sebuah tujuan dari perilaku integrasi ekonomi regional di tahun 2020, Asean Security Community dan beberapa komunitas sosial Budaya ASEAN merupakan dua pilar yang tidak bisa terpisahkan dari komunitas ASEAN.

5 Akhmad Farhan, "Perbandingan Daya Saing Indonesia Di Antara Negara-Negara ASEAN", https://www.researchgate.net/publication/295073891_Perbandingan_Daya Saing Indonesia_Diantara Ne gara-Negara_ASEAN, diakses 5 Januari 2017.

6 Ibid.

7 Joko Tri Haryanto, "Kualitas Belanja, Kinerja, dan Daya Saing Indonesia", http://www.kemenkeu.go.id/en/node/43572, diakses 7 Januari 2017.

8 Ibid. Dengan laju pertumbuhan ekonomi rata-rata 5,8\% dalam periode 10 tahun terakhir, pengelolaan ekonomi makro yang makin prudent, ditambah kualitas pertumbuhan yang inklusif dan berkelanjutan. Namun demikian, pemerintah tetap wajib memperhatikan beberapa aspek yang masih menjadi catatan, khususnya terkait dengan persoalan kesenjangan dan ketimpangan beberapa faktor dan indikator daya saing tersebut. Secara umum, penilaian terhadap indikator infrastruktur dan konektivitas mengalami perbaikan di posisi 56, lebih baik dibandingkan tahun sebelumnya. Indikator lainnya yang menunjukkan kriteria positif adalah indikator kualitas hubungan antara pemerintah dan swasta, hingga 14 peringkat di posisi 53, begitu pula indikator efisiensi pemerintahan yang berada di posisi 36.

$9 \quad$ Akhmad Farhan, Loc. cit. 
digunakan dari 0 (sangat korup) sampai 100 (sangat bersih). ${ }^{10}$ Korupsi di sektor publik akan menghambat jalannya pembangunan, meruntuhkan kepercayaan terhadap pemerintah, dan perubahan iklim usaha sehingga menimbulkan ekonomi biaya tinggi;

2) Indeks Kebebasan Ekonomi (Freedom of Economy Index). Beberapa aspek kebebasan ekonomi yang dievaluasi misalnya tingkat keterbukaan ekonomi untuk investasi global atau perdagangan. Namun sebagian besar fokus pada kebijakan dalam suatu negara, menilai kebebasan individu untuk menggunakan tenaga kerja atau keuangan tanpa ada hambatan, dan campur tangan pemerintah. ${ }^{11}$ Singapura menunjukkan dirinya sebagai salah satu negara yang memberikan kemudahan dalam melakukan aktifitas ekonomi. Dengan skor tertinggi di antara negara ASEAN yakni 89,4, Singapura menjadi urutan ke-2 dunia. Malaysia memperoleh skor 70,8 dengan urutan ke-31 sedangkan Indonesia masih tertinggal di belakang Thailand dan Filipina. Hal ini memperlihatkan bahwa kebebasan ekonomi di Indonesia masih kurang baik. Aturan hukum yang sering tumpang tindih, proses perizinan yang tidak lepas dari praktik korupsi dan lain sebagainya sering menjadi kendala aktivitas ekonomi;

3) Kemudahan dalam berbisnis (Ease of Doing Business). Data dalam The Doing Business dari Bank Dunia menggambarkan peran penting kebijakan pemerintah dalam aktivitas keseharian perusahaan kecil dan menengah. Tujuan dari laporan ini adalah untuk mendorong agar peraturan dibuat lebih efisien, dapat diakses oleh yang berkepentingan dan mudah diimplementasikan. Dengan demikian diharapkan para pengusaha (UMKM) dapat menjalankan usahanya dengan berkompetisi secara adil serta dapat mengembangkan diri dengan berinovasi. ${ }^{12}$ Indonesia hanya menempati urutan ke-114 di tingkat dunia dalam kemudahan berbisnis, tertinggal jauh dari negara-negara di sekitarnya. Singapura berada di peringkat 1, Malaysia ke-18, Thailand ke-26, Vietnam ke-78, Filipina ke-95, dan Brunei ke-101. Indonesia hanya lebih baik dari Kamboja, Laos, dan Myanmar yang ekonominya masih belum berkembang. Hal ini menggambarkan tidak mudah untuk menjalankan bisnis di Indonesia karena banyak hambatan dan rintangan yang harus dihadapi oleh investor untuk memulai usahanya.

10 Joko Tri Haryanto, Loc.cit. Singapura menempati posisi tertinggi dengan skor 84 dan menempati urutan ke-7 dunia, disusul oleh Malaysia skor 52 dan urutan ke-50, Thailand dan Filipina skor 38 dengan urutan ke-85 serta Indonesia skor 34 dan urutan ke-107. Hal ini menggambarkan bahwa Indonesia diidentikkan dengan budaya korupsi yang sudah menjalar di sektor publik.

11 Ibid. Sepuluh aspek yang diukur dari kebebasan ekonomi dapat dikelompokkan ke dalam 4 kategori besar: (1) Aturan hukum (hak milik, bebas dari korupsi); (2) Ukuran pemerintah (kebebasan fiskal, pengeluaran pemerintah); (3) Efisiensi regulasi (kebebasan bisnis, kebebasan tenaga kerja, kebebasan moneter); dan (4) Keterbukaan pasar (kebebasan perdagangan, kebebasan investasi, kebebasan finansial). 
Sementara di negara-negara lain, investor diberikan kemudahan agar mau menjalankan bisnis di negara tersebut. Birokrasi yang mudah, murah, dan cepat adalah daya tarik bagi para pengusaha untuk membuka usaha di suatu negara; ${ }^{13}$ dan

4) Indeks Daya Saing Global (Global Competitiveness Index/GCI). Perbedaan dalam menentukan faktor penentu ini telah diadopsi dalam $\mathrm{GCl}$ dengan memasukkan rata-rata tertimbang dari berbagai komponen yang berbeda, masing-masing mengukur aspek yang berbeda dari daya saing. ${ }^{14}$ Indeks daya saing global menunjukkan Indonesia berada di posisi ke-4 di antara negara anggota ASEAN dan urutan ke-34 di dunia. ${ }^{15}$ Kategori persyaratan dasar (basic requirement) yang menjadi salah satu aspek dari penilaian $\mathrm{GCl}$, mengakibatkan Indonesia skornya tertinggal dibandingkan dengan kompetitor terdekatnya, yaitu Thailand dan Malaysia. Hanya pada aspek institusi, Indonesia lebih baik dari Thailand dan lingkungan makro ekonomi Indonesia lebih tinggi skornya dari Malaysia. Begitu juga jika dilihat dari 2 kategori yang lain yaitu pendorong efisiensi (efficiency enhancer) dan faktor inovasi dan kecanggihan. Indonesia harus mengakui masih banyak yang perlu diperbaiki, pasar barang dan tenaga kerja belum efisien, penggunaan teknologi masih belum lengkap, pendidikan tinggi dan pelatihan sumber daya manusia (SDM) yang masih perlu dibenahi, ${ }^{16}$ serta dari sisi aspek perundang-undangan.

Kondisi faktual tersebut memerlukan upaya untuk melakukan berbagai kebijakan integral, yaitu melalui re-evaluasi terhadap perundang-undangan berupa pembangunan hukum agar dapat mendorong peningkatan daya saing terutama UMKM pasca berlakunya MEA 2015. Secara mikro, hal ini berakibat positif bagi pertumbuhan ekonomi UMKM dalam meningkatkan kesejahteraannya, sedangkan dalam tataran makro, pertumbuhan ekonomi tersebut secara kumulatif dapat mencerminkan keadaan ekonomi Indonesia dibandingan dengan negara-negara lainnya sekaligus memposisikan kedudukan Indonesia sebagai negara berdaya saing tinggi di antara negara-negara ASEAN.

13 Ibid. Salah satu alasan mengapa Indonesia dianggap sebagai negara yang sulit untuk memulai bisnis dikarenakan investor yang akan memulai bisnis di Indonesia memerlukan 10 prosedur dan 52,5 hari kerja, dibandingkan dengan Singapura yang hanya membutuhkan 3 tahapan dan 2,5 hari kerja saja. Begitu juga dengan pengusaha yang akan melakukan kegiatan ekspor dan impor. Untuk ekspor hanya memerlukan 4 dokumen dengan proses selama 17 hari dan biaya mencapai USD572. Sementara untuk impor, diperlukan 4 dokumen selama 26 hari kerja dengan biaya USD647 per kontainer. Apabila dibandingkan dengan Malaysia, Indonesia kalah dalam tingkat efisiensi. Untuk ekspor, Malaysia perlu 4 dokumen dengan 11 hari kerja dan biaya USD525, begitu dengan impor yang hanya membutuhkan 8 hari kerja dengan biaya USD560 per kontainer.

14 Ibid.

15 Ibid. Singapura berada di depan, bahkan menjadi peringkat 2 di dunia, Malaysia berada di urutan berikutnya dengan urutan ke-20 sedangkan Thailand berada di urutan ke-31.

16 Ibid. 
Kajian ini berbeda dengan penelitian sebelumnya yang dilakukan oleh Setyani Irmawati dengan judul "Strategi Peningkatan Daya Saing Industri Unggulan Provinsi Jawa Tengah untuk Menghadapi ASEAN Economic Community (AEC) 2015", ${ }^{17}$ yang mengkaji secara khusus di tempat tertentu dengan pendekatan ekonomi, sedangkan kajian ini bersifat umum melalui pendekatan normatif.

\section{B. Peningkatan Daya Saing Usaha Mikro, Kecil, dan Menengah Melalui Pembangunan Hukum Sebelum dan Pasca Berlakunya Masyarakat Ekonomi ASEAN 2015}

Indonesia merupakan negara hukum dalam arti materil atau negara kesejahteraan yang mengandung makna bahwa negara memiliki tanggung jawab untuk mensejahterakan rakyatnya. Hal itu sejalan dengan salah satu tujuan nasional sebagaimana tercantum dalam Alinea IV Pembukaan Undang-Undang Dasar 1945 (UUD 1945), yaitu memajukan kesejahteraan umum melalui pembangunan, terutama pemberdayaan UMKM yang mempunyai peran sentral dalam aktivitas ekonomi nasional. Berkaitan dengan hal itu, fungsi negara dapat dibagi menjadi 2 bagian, yakni: pertama, fungsi reguler meliputi politik, diplomatik, yuridis, dan administratif; dan kedua, fungsi pembangunan. ${ }^{18}$ Pembangunan dalam arti luas meliputi semua bidang kehidupan termasuk hukum, ${ }^{19}$ sehingga diperlukan pembangunan hukum khususnya berkaitan dengan peningkatan daya saing UMKM untuk mengantisipasi globalisasi ekonomi (MEA).

Mochtar Kusumaatmadja mengemukakan Teori Hukum Pembangunan, yaitu peranan hukum untuk menjamin bahwa perubahan yang itu terjadi dengan cara yang teratur. ${ }^{20}$ Selain itu, teori tersebut juga menjelaskan konsepsi hukum sebagai sarana pembaharuan adalah hukum dalam arti kaedah atau peraturan hukum memang dapat berfungsi sebagai pengatur ke arah kegiatan manusia yang dikehendaki oleh pembangunan atau pembaharuan. ${ }^{21}$

Pemikiran tentang hukum sebagai alat pembaharuan dalam masyarakat berasal dari pendapat Roscoe Pound. Disesuaikan dengan situasi dan kondisi di Indonesia, konsepsi 'Law as a tool of social engineering' yang merupakan inti pemikiran dari aliran Pragmatical Legal Realism itu oleh Mochtar Kusumaatmadja kemudian

17 Lihat Setyani Irmawati, "Strategi Peningkatan Daya Saing Industri Unggulan Provinsi Jawa Tengah untuk Menghadapi ASEAN Economic Community (AEC) 2015", Skripsi, Fakultas Ekonomi Universitas Negeri Semarang, 2015, http://lib.unnes.ac.id/22269/1/7111411053-s.pdf, diakses 17 Januari 2017.

18 Muchsan, Sistem Pengawasan terhadap Perbuatan Aparat Pemerintah dan Peradilan Tata Usaha Negara di Indonesia Yogjakarta: Liberty, 1992, hlm 5-6 sebagaimana dikutip oleh Ibrahim R, Prospek BUMN dan Kepentingan Umum, Bandung: PT Citra Aditya Bakti, 1997, hlm. 10.

19 Permasalahan dalam penyelenggaraan sistem dan politik hukum pada dasarnya meliputi substansi hukum, struktur hukum, dan budaya hukum.

20 Mochtar Kusumaatmadja, Konsep-Konsep Hukum dalam Pembangunan, Bandung: Alumni, 2002, hlm. 19.

21 Mochtar Kusumaatmadja, Hukum, Masyarakat dan Pembinaan Hukum Nasional, Jakarta: Bina Cipta, 1976, hIm. 4. 
dikembangkan di Indonesia. ${ }^{22}$ Dengan demikian, hukum tidak sekedar meneguhkan pola-pola yang memang telah ada dalam masyarakat, melainkan berusaha untuk menciptakan hal-hal atau hubungan-hubungan yang baru, ${ }^{23}$ sehingga dapat disimpulkan bahwa perspektif yang dominan di Indonesia menunjukan pentingnya hukum sebagai sarana bagi perubahan-perubahan sosial atau sarana pembangunan. ${ }^{24}$ Sejalan dengan pendapat tersebut, Friedman mengatakan bahwa hukum sebagai rekayasa sosial tidak pasif, melainkan harus mampu digunakan untuk mengubah suatu keadaan dan kondisi tertentu ke arah yang dituju sesuai dengan kemauan masyarakat, ${ }^{25}$ sehingga hukum berfungsi sebagai agent of modernization and instrument of social engineering. ${ }^{26}$

Komar Kantaatmadja menjelaskan bahwa yang dimaksud dengan hukum sebagai sarana pembaharuan adalah "hukum harus mampu memenuhi kebutuhan sesuai dengan tingkat kemajuan serta tahapan pembangunan di segala bidang, sehingga dapat diciptakan ketertiban dan kepastian hukum untuk menjamin serta memperlancar pelaksanaan pembangunan ${ }^{2} .{ }^{27}$ Karena itu, hukum menjadi suatu alat yang tidak dapat diabaikan dalam proses pembangunan. ${ }^{28}$ Sedangkan Sunaryati Hartono ${ }^{29}$ menyebutkan tentang makna dari pembangunan hukum, yaitu: menyempurnakan (membuat sesuatu yang lebih baik); mengubah agar menjadi lebih baik dan modern; mengadakan sesuatu yang sebelumnya belum ada; atau meniadakan sesuatu yang terdapat dalam sistem lama karena tidak diperlukan dan tidak cocok dengan sistem baru. Pembangunan hukum tersebut harus berkesinambungan agar tidak ketinggalan dalam proses pembangunan, sebab pembangunan menghendaki adanya konsepsi hukum yang berfungsi mendorong dan mengarahkan pembangunan sebagai cerminan dari tujuan hukum modern. ${ }^{30}$

Pembangunan hukum dilakukan melalui penetapan kebijaksanaan mengenai perkembangan hukum, yaitu pembinaan hukum di bidang-bidang hukum yang dapat diperbaharui dan bidang-bidang hukum yang sebaiknya dibiarkan dulu. Secara umum dapat dikatakan bahwa bidang-bidang hukum yang erat kaitannya

22 Ibid, hlm. 9. Lihat juga Lili Rasjidi dan Ira Rasjidi, Dasar-dasar Filsafat dan Teori Hukum, PT Citra Aditya Bakti, Bandung, 2001, hlm. 78-79.

23 Satjipto Rahardjo, Pemanfaatan Ilmu-Ilmu Sosial bagi Pengembangan Studi Hukum, Cetakan ke-1, Bandung: Alumni, 1977, hlm. 143-145.

24 Mulyana W. Kusumah, Peranan dan Pendayagunaan Hukum dalam Pembangunan, Bandung: Alumni, 1982, hlm. 4.

25 W. Friedman, Legal Theory, dalam buku Perlindungan Desain Tata Letak Sirkuit Terpadu, yang disusun oleh Sudjana, Bandung: Widya Padjadjaran, 2011, hlm. 14

26 Sumantoro, Hukum Ekonomi, Jakarta: UI Press, 1986, hlm. 180.

27 Komar Kantaamadja, "Peran dan Fungsi Profesi Hukum dalam Undang-undang Perpajakan”, Makalah dalam Seminar Nasional Hukum Pajak IMNO-UNPAD, Juli 1985.

28 Mochtar Kusumaatmadja, Konsep-Konsep Hukum..., Op.cit., hlm. 20.

29 Sunaryati Hartono, "Sejarah Perkembangan Hukum Nasional Indonesia Menuju Sistem Hukum Nasional", Makalah, 1991.

30 Bandingkan dengan Sunaryati Hartono, Ibid. 
dengan kehidupan budaya dan spiritual masyarakat sementara dibiarkan dahulu, sedangkan yang bidang-bidang hukum yang bersifat netral lebih tepat bagi usaha pembaharuan. ${ }^{31}$ Salah satu bidang hukum yang bersifat netral adalah Hukum Perusahaan, khususnya berkaitan dengan pemberdayaan UMKM.

Pemberdayaan UMKM perlu diselenggarakan secara menyeluruh, optimal, dan berkesinambungan melalui pengembangan iklim yang kondusif, pemberian kesempatan berusaha, dukungan, perlindungan, dan pengembangan usaha seluasluasnya, sehingga mampu meningkatkan kedudukan, peran, dan potensi UMKM dalam mewujudkan pertumbuhan ekonomi, pemerataan dan peningkatan pendapatan rakyat, penciptaan lapangan kerja, dan pengentasan kemiskinan. ${ }^{32}$ Salah satu prinsip pemberdayaan UMKM adalah peningkatan daya saing, ${ }^{33}$ yang sejalan dengan Teori Keunggulan Komparatif dan Kompetitif (David Ricardo dan John Stuart Mill) dan Teori Daya Saing Model Diamond Porter (Michael Porter) yang dilengkapi oleh Teori Daya Saing Model Sembilan Faktor (Dong-Sung Cho).

Tujuan pemberdayaan UMKM yaitu menumbuhkan dan mengembangkan kemampuan UMKM menjadi usaha yang tangguh dan mandiri. ${ }^{34}$ Usaha kecil adalah usaha ekonomi produktif yang berdiri sendiri, yang dilakukan oleh orang perorangan atau badan usaha yang bukan merupakan anak perusahaan atau bukan cabang perusahaan yang dimiliki, dikuasai, atau menjadi bagian baik langsung maupun tidak langsung dari usaha menengah atau usaha besar yang memenuhi kriteria usaha kecil. ${ }^{35}$ Usaha menengah adalah usaha ekonomi produktif yang berdiri sendiri, yang dilakukan oleh orang perorangan atau badan usaha yang bukan merupakan anak perusahaan atau cabang perusahaan yang dimiliki, dikuasai, atau menjadi bagian baik langsung maupun tidak langsung dengan usaha kecil atau usaha besar dengan jumlah kekayaan bersih atau hasil penjualan tahunan. ${ }^{36}$ Sedangkan Kriteria UMKM didasarkan pada memiliki kekayaan bersih dan memiliki hasil penjualan tahunan. ${ }^{37}$

Vukovik (et.al) mengatakan bahwa daya saing (competitiveness) memiliki beberapa definisi dan teori. ${ }^{38}$ WEF mendefinisikan daya saing sebagai seperangkat institusi, kebijakan, dan faktor-faktor yang menentukan tingkat produktivitas suatu negara. Tingkat produktivitas akan menentukan tingkat kemakmuran yang dapat

31 Mochtar Kusumaatmadja, Konsep-Konsep Hukum..., Op.cit., hlm. 23-24.

32 Bagian Menimbang Undang-Undang Nomor 20 Tahun 2008 Tentang Usaha Mikro, Kecil, dan Menengah (UU UMKM).

33 Pasal 4 huruf d UU UMKM.

34 Selengkapnya tujuan pemberdayaan UMKM diatur dalam Pasal 5 UU UMKM.

35 Pasal 1 angka 2 UU UMKM.

36 Pasal 1 angka 3 UU UMKM.

37 Lihat Pasal 6 UU UMKM.

38 Vukovic, D., Jovanovic, A., dan Djukic, M, "Defining Competitiveness through the Theories of New Economic Geography and Regional Economy", Journal of the Geographical Institute Jovan Cvijic, SASA, 62(3), 2012, hlm 49-64. 
dicapai dengan ekonomi dan tingkat pengembalian investasi dalam perekonomian, yang akan menjadi pendorong utama tingkat pertumbuhan. ${ }^{39}$ Sedangkan menurut Michael E. Porter, daya saing adalah fondasi kemakmuran berdasarkan potensi produktif perekonomian suatu negara yang pada gilirannya akhirnya ditetapkan oleh produktivitas perusahaan yang ditentukan oleh kecanggihan operasi dan strategi perusahaan serta kualitas lingkungan bisnis ekonomi mikro. ${ }^{40}$

Pendekatan yang sering digunakan untuk mengukur daya saing dilihat dari beberapa indikator yaitu keunggulan komperatif dan keunggulan kompetitif. Menurut Tarigan, keunggulan komperatif adalah suatu kegiatan ekonomi yang menurut perbandingan lebih menguntungkan bagi pengembangan daerah. Lebih lanjut, istilah comparative advantage (keunggulan komparatif) mula-mula dikemukakan oleh David Ricardo sewaktu membahas perdagangan antara dua negara. ${ }^{41}$ Dalam teori tersebut, Ricardo membuktikan bahwa apabila ada dua negara saling berdagang dan masing-masing negara mengkonsentrasikan diri untuk mengekspor barang yang bagi negara tersebut memiliki keunggulan yang komperatif maka kedua negara tersebut akan beruntung. Keunggulan kompetitif merupakan ukuran daya saing, yaitu kemampuan suatu negara atau suatu daerah untuk memasarkan produknya di luar daerah atau luar negeri. ${ }^{42}$

Teori Keunggulan Komparatif yang dikemukakan oleh John Stuart Mill sebagaimana dikutip oleh Nopirin, ${ }^{43}$ menyatakan bahwa suatu negara akan menghasilkan dan kemudian mengekspor suatu komoditas yang memiliki comparative advantage terbesar yaitu suatu komoditas yang dapat dihasilkan dengan lebih murah dan mengimpor komoditas yang memiliki comparative disadvantage yaitu komoditas yang apabila dihasilkan sendiri memerlukan biaya yang besar. Teori ini pada dasarnya menyatakan bahwa nilai suatu komoditas ditentukan oleh banyaknya tenaga kerja yang dicurahkan untuk memproduksi barang tersebut. Semakin banyak tenaga yang dicurahkan untuk memproduksi komoditas tersebut, maka akan semakin mahal nilai komoditas tersebut. ${ }^{44}$

Michael E. Porter sebagaimana dikutip oleh dalam R Hendra Halwani ${ }^{45}$ dalam bukunya yang terkenal, The Competitive Advantage of Nation, mengemukakan

39 Akhmad Farhan, Loc.cit.

40 Ibid.

41 Suci Ana Winta Ritonga, "Analisis Determinan Daya Saing Ekonomi Kabupaten Batu Bara", http://repository.usu.ac.id/bitstream/123456789/50293/3/Chapter\%20ll.pdf, diakses 15 Januari 2017.

42 Akhmad Farhan, Loc.cit. Menurut Tarigan, seorang perencana wilayah harus memiliki kemampuan untuk menganalisa potensi ekonomi wilayahnya. Dalam hal ini kemampuan pemerintah daerah untuk melihat sektor yang memiliki keunggulan/kelemahan di wilayahnya menjadi semakin penting. Sektor ini memilik keunggulan, memiliki prospek yang lebih baik untuk dikembangkan dan diharapkan dapat mendorong sektor-sektor lain untuk berkembang.

43 Nopirin, Ekonomi Internasional, Yogyakarta: BPFE, 2012, hlm 7-35

44 Akhmad Farhan, Loc.cit.

45 Bandingkan dengan R. Hendra Halwani, Ekonomi Internasional dan Globalisasi Ekonomi, Edisi Kedua, Bogor: Ghalia Indonesia, 2005, hIm. 43-44 
adanya korelasi langsung antara dua faktor produksi (sumber daya alam yang melimpah dan sumber daya manusia yang murah) yang dimiliki suatu negara yang dimanfaatkan menjadi keunggulan daya saing dalam perdagangan internasional. Namun banyak negara yang memiliki jumlah tenaga kerja yang sangat besar tetapi memiliki daya saing perdagangan internasional yang terbelakang. Begitu juga dengan tingkat upah yang relatif murah, justru berkorelasi erat dengan rendahnya motivasi bekerja keras dan berprestasi.

Hasil akhir Porter menyebutkan bahwa peran pemerintah sangat mendukung dalam peningkatan daya saing selain faktor produksi yang tersedia. Industri suatu negara yang sukses dalam skala internasional pada umumnya didukung oleh 4 atribut, yaitu: (1) kondisi faktor produksi yang baik; (2) permintaan dan tuntutan mutu dalam negeri yang tinggi; (3) industri hulu atau hilir yang maju; dan (4) persaingan domestik yang ketat. Keunggulan kompetitif yang hanya didukung oleh satu atau dua atribut saja biasanya tidak akan dapat bertahan, sebab keempat atribut tersebut saling berinteraksi positif pada negara yang sukses dalam meningkatkan daya saing. Di samping peluang, peran pemerintah juga merupakan variabel tambahan yang cukup signifikan seperti penerapan kebijakan antitrust, regulasi, deregulasi, atau kondisi konsumen. ${ }^{46}$

Teori Daya Saing Model Diamond Porter menjelaskan bahwa suatu negara secara nasional dapat meraih keunggulan kompetitif apabila memenuhi empat persyaratan yang saling terkait tersebut dan membentuk empat titik sudut dari poin yang dinamakan bangunan intan. Semakin tinggi tingkat persaingan perusahaan di suatu negara, maka semakin tinggi tingkat daya saing internasionalnya. ${ }^{47}$ Kemudian Teori Daya Saing Model Sembilan Faktor oleh Dong-Sung Cho, melengkapi hasil kajian dari Michael E. Porter. Cho menerangkan bahwa Model Diamond Porter menunjukkan industri dapat mempertahankan daya saing internasional pada saat keempat penentu tersebut ada, tetapi teori tersebut menjelaskan perekonomian di negara maju. Sehingga modelnya perlu dimodifikasi agar dapat diterapkan pada negara yang sedang berkembang atau terbelakang karena negara tersebut harus mampu menciptakan daya saing internasional tanpa selalu memiliki salah satu dari empat penentu tersebut. ${ }^{48}$

Analisis Porter tidak mampu menjelaskan keberhasilan yang telah dicapai oleh Korea maupun Taiwan pada abad ke-20. Karena itu, suatu model yang baru harus mencapai dua sasaran yaitu pertama, lebih baik dalam mengevaluasi elemen manakah yang telah memberikan kontribusi pada daya saing internasional dari

46 Apabila ingin memenangkan kompetisi, terdapat 5 kekuatan yang harus menjadi bahan pertimbangan, yaitu meliputi: (1) karakter persaingan di antara pesaing; (2) ancaman masuknya pesaing baru; (3) ancaman dari produk atau jasa pengganti; (4) bargaining position pemasok; dan (5) bargaining position konsumen. Penjelasan lebih lanjut lihat Setyani Irmawati, Loc.cit.

47 Ibid.

48 lbid. 
perekonomian negara terbelakang, dan kedua, mampu menunjukkan sebuah negara dapat memperbaiki keunggulan nasionalnya. ${ }^{49}$ Model sembilan faktor memiliki empat penentu fisik dari daya saing internasional, yaitu: (1) sumber daya yang dianugerahkan; (2) lingkungan bisnis; (3) industri terkait dan pendukung; serta (4) permintaan domestik. Selain faktor fisik, terdapat pula empat faktor manusia, yakni: (1) pekerja; (2) politisi dan birokrat; (3) para wirausahawan; serta (4) manajer dan insinyur yang profesional. Kemudian faktor terakhir adalah peristiwa peluang eksternal. ${ }^{50}$

MEA memiliki pola mengintegrasikan ekonomi ASEAN dengan cara membentuk sistem perdagangan bebas atau free trade antara negara-negara anggota ASEAN. ${ }^{51}$ Para anggota negara ASEAN termasuk Indonesia yang telah menyepakati perjanjian tersebut perlu menyesuaikan kebijakan ekonominya melalui pembangunan hukum baik berupa revisi atau perubahan dan pembaruan terhadap hukum yang sudah ada atau pembentukan hukum yang baru untuk mengantisipasi akibat kesepakatan integrasi ekonomi, yaitu semakin ketatnya daya saing produk, demi peningkatan daya saing UMKM dan taraf hidup serta tingkat kesejahteraan seluruh rakyat Indonesia.

MEA merupakan bentuk kerja sama ${ }^{52}$ dengan ciri-ciri utama, yaitu: ${ }^{53}$ 1) Kawasan ekonomi yang sangat kompetitif; 2) Memiliki wilayah pembangunan ekonomi yang merata; 3) Daerah-daerah akan terintegrasi secara penuh dalam ekonomi global; dan 4) Basis dan pasar produksi tunggal. Sedangkan langkah-langkah strategis UMKM serta pemerintah dalam menghadapi MEA meliputi: ${ }^{54}$ meningkatkan keunggulan kompetitif UMKM; meningkatkan penggunaan teknologi; penguatan daya saing; pengamanan pasar domestik; penguatan ekspor; bimbingan yang berkesinambungan; serta koordinasi dan sinergitas aparat pusat dan daerah.

Kebijakan industri nasional berkaitan dengan peningkatan daya saing Indonesia dilakukan melalui penguatan struktur industri dan peningkatan dukungan iklim

49 Ibid.

50 lbid.

51 ASEAN, “ASEAN Economic Community (AEC)", http://www.asean.org/storage/2012/05/56.-December-2015Fact-Sheet-on-ASEAN-Economic-Community-AEC-1.pdf, diakses 18 Januari 2017.

52 Bentuk kerja sama MEA ialah: pengembangan pada sumber daya manusia dan adanya peningkatan kapasitas; pengakuan terkait kualifikasi profesional; konsultasi yang lebih dekat terhadap kebijakan makro keuangan dan ekonomi; memiliki langkah-langkah dalam pembiayaan perdagangan; meningkatkan infrastruktur; melakukan pengembangan pada transaksi elektronik lewat e-ASEAN; memperpadukan segala industri yang ada di seluruh wilayah untuk dapat mempromosikan sumber daerah; dan meningkatkan peran dari sektor swasta untuk dapat membangun MEA. Purnama Kusumaastuti, Ega Maharani Asih, Carmidah, "Strategi dan Langkah-Lagkah UMKM dalam Menghadapi Masyarakat Ekonomi ASEAN (MEA) 2015", Journal \& Proceeding FEB Unsoed, Vol. 5, No. 1, 2015, http://jp.feb.unsoed.ac.id/index.php/sca-1/article/viewFile/641/pdf 84, diakses 19 Januari 2017.

$53 \quad$ lbid.

54 Penjelasan selengkapnya lihat dalam Ibid. 
industri. ${ }^{55}$ Penguatan struktur industri dilakukan melalui pengembangan kemampuan sektor industri dan pasar dalam negeri dan ASEAN sebagai base-load. ${ }^{56}$ Peningkatan dukungan iklim industri dilakukan melalui: (1) meningkatkan daya saing short term; (2) meningkatkan daya saing medium term; dan (3) meningkatkan daya saing long term. ${ }^{57}$ Kebijakan tersebut perlu memperhatikan keunggulan kompetitif yang dimiliki Indonesia dan mengantisipasi kelemahan-kelemahannya, agar ketiga faktor tersebut dapat menjadi daya dorong dalam peningkatan daya saing, khususnya bagi UMKM. Peningkatan daya saing sebagai inti peningkatan dukungan iklim industri perlu mendapat dukungan legislasi, dalam arti peraturan perundang-undangan terkait harus mendukung kepentingan nasional yaitu perlindungan industri UMKM, tetapi di lain pihak juga harus dapat memanfaatkan pasar ASEAN (MEA) untuk mengakomodasi kepentingan nasional dalam hubungan internasional atau regional.

Jika melihat blueprint MEA, terdapat beberapa pengaturan di bidang hukum yang perlu untuk segera ada penyesuaian (adjustment). Setidaknya terdapat 14 bidang pengaturan peraturan perundang-undangan yang perlu untuk disesuaikan dengan akan berlakunya MEA tersebut. Bidang-bidang itu adalah perdagangan, perindustrian, investasi, tenaga kerja, pangan, pertanian, kehutanan, perpajakan, perlindungan konsumen, kekayaan intelektual, transportasi udara, kesehatan, pariwisata, serta usaha kecil dan menengah. ${ }^{58}$

55 Kacung Abdullah, "Kesiapan Industri Kecil Menengah dalam Rangka Menyongsong Masyarakat Ekonomi ASEAN (MEA) 2015", Presentasi disampaikan oleh Dirjen IKM pada acara launching Aplikasi International Trade and Investment Summit 2015 di Jakarta, 28 Agustus 2014, https://www.slideshare.net/abdul300483/ kesiapan-ikm-menghadapi-mea-2015, diakses 20 Januari 2017.

56 Ibid. Penguatan struktur industri dilakukan dengan cara: 1) Pengembangan kemampuan industri dalam jangka waktu panjang (35 klaster industri dalam Peraturan Presiden Nomor 28 Tahun 2008 tentang Kebijakan Industri Nasional-Perpres 28/2008); dan 2) percepatan pengembangan sektor indutri hingga 2015: a. industri hilir berbasis agro, migas dan bahan tambang mineral; b. industri berbasis SDM dan pasar domestik; c. Industri kecil dan menengah, dll.

Sedangkan memanfaatkan pasar dalam negeri dan ASEAN sebagai base-load melalui peningkatan enforcement; pengaturan lebih lanjut pelabuhan; membangun peraturan teknis untuk menghilangkan impor produk tidak standar; meningkat compliance produk ke ASEAN; membangun kemampuan market \& industrial intelligence; membangun early warning system; membangun kemampuan advocacy ekspor ke ASEAN dan membangun produk spesifik Indonesia.

57 Ibid. (1) Meningkatkan daya saing (short term) meliputi: menurunkan biaya modal, biaya energi dan biaya manpower serta biaya logistik; ketersediaan bahan baku; biaya logistik iklim investasi (perizinan, pungli; insentif fiskal, bea masuk ditanggung pemerintah); (2) Meningkatkan daya saing (medium term), meliputi: jaminan pasokan impor untuk meredam produk ilegal; optimalisasi peningkatan penggunaan produksi dalam negeri (P3DN); menghilangkan gangguan keamanan; (3) Meningkatkan daya saing (long term) meliputi: peningkatan faktor pendukung industri; membangun kemampuan sumber daya manusia industri; dan membangun R\&D (research \& development) Industri.

58 Rencana Pembangunan Jangka Panjang Nasional (RPJPN) sebagaimana dikutip oleh Akhmad Aulawi, "Arah Pembangunan Hukum Dalam Menghadapi ASEAN Economic Community 2015", Jurnal Rechtvinding, Badan Pembinaan Hukum Nasional (BPHN), hlm 4 tersedia dalam http://rechtsvinding.bphn.go.id/view/view_online.php?id=21.diakses 25 Januari 2017. 
Terdapat dua hal yang perlu dilakukan dalam menyesuaikan arah pembangunan hukum nasional dengan akan diselenggarakannya MEA 2015. Pertama, perlu membuat grand design arah pembangunan hukum nasional yang mengadopsi nilai dan tujuan MEA atau pun forum internasional lainnya yang dapat mempengaruhi pembangunan hukum nasional Indonesia. Kedua, menyesuaikan substansi atau muatan yang terdapat dalam 14 bidang peraturan perundang-undangan yang terkait dengan pelaksanaan MEA. Dalam membuat grand design arah harus sejalan dengan semangat dan tujuan MEA dengan tetap mengedepankan koridor dalam Rencana Pembangunan Jangka Panjang Nasional (RPJPN) dan kondisi sosiokultural masyarakat Indonesia. ${ }^{59}$

RPJPN 2005-2025 sebagaimana tertuang dalam Undang-Undang Nomor 17 Tahun 2007 (UU RPJPN 2005-2025) belum terlihat secara konkret dukungan pembangunan hukum nasional dalam menghadapi perubahan perdagangan internasional yang salah satunya dalam bentuk MEA. Dalam salah satu visi pembangunan nasional yang tertera dalam RPJPN disebutkan bahwa visi pembangunan nasional bertujuan untuk mewujudkan Indonesia berperan penting dalam pergaulan dunia Internasional. ${ }^{60}$ Selanjutnya, dalam RPJPN 2005-2025, tercantum arah pembangunan dalam rangka menciptakan bangsa Indonesia yang berdaya saing khususnya dalam memperkuat perekonomian domestik dengan orientasi dan berdaya saing global. ${ }^{61}$ Oleh karena itu, perlu implementasi hukum sebagai sarana perubahan masyarakat dalam arti pembangunan hukum mengarahkan tujuan yang hendak dicapai yaitu mengantisipasi perubahan perdagangan global.

Indonesia telah memberlakukan hukum persaingan berperan aktif menjadi centre of excellence dalam pengembangan hukum persaingan usaha di ASEAN melalui pembagian pengalaman. ${ }^{62}$ Dalam perspektif kompetisi, konsekuensi terbukanya pasar akibat peredaran barang dan jasa adalah persaingan baru, pasar bersangkutan baru dan potensi ketersentuhan pelaku usaha Indonesia dengan hukum persaingan negara-negara tetangga. ${ }^{63}$ Oleh karena itu, evaluasi ulang terhadap Undang-Undang Nomor 5 Tahun 1999 Tentang Larangan Praktek

$59 \quad$ Ibid.

60 Ibid.

61 Ibid. Untuk itu perlu melakukan: (1) pengembangan rantai pertambahan nilai melalui diversifikasi produk (pengembangan ke hilir), pendalaman struktur ke hulu, atau pengembangan secara menyeluruh (hulu-hilir); (2) penguatan hubungan antar industri yang terkait secara horizontal termasuk industri pendukung dan industri komplemen, termasuk dengan jaringan perusahaan multinasional terkait, serta penguatan hubungan dengan kegiatan sektor primer dan jasa yang mendukungnya; dan (3) penyediaan berbagai infrastruktur bagi peningkatan kapasitas kolektif, antara lain, meliputi sarana dan prasarana fisik (transportasi, komunikasi, energi, serta sarana dan prasarana teknologi; prasarana pengukuran, standardisasi, pengujian, dan pengendalian kualitas; serta sarana dan prasarana pendidikan dan pelatihan tenaga kerja industri).

62 Masnur Tiurmaida Malau, “Aspek Hukum Peraturan dan Kebijakan Pemerintah Indonesia dalam menghadapi Liberalisasi Ekonomi Regional: Masyarakat Ekonomi Asean 2015", Jurnal Rechtvinding, Vol. 3, No. 2, Agustus 2014, BPHN, hlm. 169 tersedia dalam 27 Januari 2017.

63 Ibid. 
Monopoli dan Persaingan Usaha Tidak Sehat (UU LPM dan PUTS) agar sesuai dengan perdagangan global perlu dilakukan melalui pembaruan hukum terutama berkaitan dengan persaingan usaha antar negara.

Pembangunan hukum dalam arti pembentukan hukum yang telah dilakukan pemerintah sebelum MEA berlaku berkaitan dengan perdagangan adalah disahkannya Undang-Undang Nomor 7 Tahun 2014 tentang Perdagangan (UU Perdagangan). Dalam pertimbangan UU tersebut dijelaskan:

“... b. Pelaksanaan demokrasi ekonomi yang dilakukan melalui kegiatan Perdagangan merupakan penggerak utama dalam pembangunan perekonomian nasional yang dapat memberikan daya dukung dalam meningkatkan produksi dan memeratakan pendapatan serta memperkuat daya saing Produk Dalam Negeri.

c. Peranan Perdagangan sangat penting dalam meningkatkan pembangunan ekonomi, tetapi dalam perkembangannya belum memenuhi kebutuhan untuk menghadapi tantangan pembangunan nasional sehingga diperlukan keberpihakan politik ekonomi yang lebih memberikan kesempatan, dukungan, dan pengembangan ekonomi rakyat yang mencakup koperasi serta usaha mikro, kecil, dan menengah sebagai pilar utama pembangunan ekonomi nasional.

d. Peraturan perundang-undangan di bidang Perdagangan mengharuskan adanya harmonisasi ketentuan di bidang Perdagangan dalam kerangka kesatuan ekonomi nasional guna menyikapi perkembangan situasi Perdagangan era globalisasi pada masa kini dan masa depan. ..."

Kebijakan pemerintah melalui UU Perdagangan menunjukkan upaya untuk mengantisipasi perkembangan ekonomi global tetapi melindungi kepentingan nasional masyarakat Indonesia terutama dalam rangka meningkatkan persaingan yang kompetitif pada MEA 2015, karena MEA mendasarkan kegiatannya pada freedom, terutama pasar bebas antara negara-negara ASEAN. Hal ini dapat dilihat dari substansi UU Perdagangan yang menerapkan sistem ekonomi campuran, yaitu pemerintah mengelola sektor ekonomi dan bahan pokok yang berkaitan dengan dengan hajat hidup orang banyak, namun tetap mengizinkan sektor swasta untuk ikut berpartisipasi dalam aktivitas perekonomian melalui MEA $2015 .^{64}$

Pembaruan hukum di bidang perindustrian dilakukan dengan disahkannya Undang-Undang Nomor 3 Tahun 2014 tentang Perindustrian (UU Perindustrian) yang menggantikan Undang-Undang Nomor 5 Tahun 1984 tentang Perindustrian yang dianggap sudah tidak sesuai dengan perubahan paradigma pembangunan

64 Amrina Rosyada, "Undang-Undang Nomor 7 Tahun 2014: Bentuk Strategi atau Bentuk Ketidakpercayaan Diri dalam Menghadapi ASEAN Economic Community 2015?", https://ideasforaec.wordpress.com/2015/10/18/ undang-undang-nomor-7-tahun-2014-bentuk-strategi-atau-bentuk-ketidakpercayaan-diri-dalammenghadapi-asean-economic-community-2015/, diakses 21 Januari 2017. 
industri. Bagian Menimbang UU Perindustrian huruf c mengatakan:

"Pembangunan industri yang maju diwujudkan melalui penguatan struktur Industri yang mandiri, sehat, dan berdaya saing, dengan mendayagunakan sumber daya secara optimal dan efisien, serta mendorong perkembangan industri ke seluruh wilayah Indonesia dengan menjaga keseimbangan kemajuan dan kesatuan ekonomi nasional yang berlandaskan pada kerakyatan, keadilan, dan nilai-nilai luhur budaya bangsa dengan mengutamakan kepentingan nasional."

Selanjutnya Penjelasan Umum UU Perindustrian berbunyi:

"Globalisasi dan liberalisasi membawa dinamika perubahan yang sangat cepat dan berdampak luas bagi perekonomian nasional. Di satu sisi pengaruh yang paling dirasakan adalah terjadi persaingan yang semakin ketat dan di sisi lain membuka peluang kolaborasi sehingga pembangunan Industri memerlukan berbagai dukungan dalam bentuk perangkat kebijakan yang tepat, perencanaan yang terpadu, dan pengelolaan yang efisien dengan memperhatikan prinsip-prinsip tata kelola yang baik."

Salah satu alat untuk meningkatkan mutu, efisiensi produksi, memperlancar transaksi perdagangan (termasuk industri), mewujudkan persaingan usaha yang sehat dan transparan, maka pemerintah mengeluarkan Undang-Undang Nomor 20 Tahun 2014 tentang Standardisasi dan Penilaian Kesesuaian (UU SPK). ${ }^{65}$ Penjelasan Umum UU tersebut mengatakan:

"Bangsa Indonesia harus memiliki daya saing sehingga mampu mengambil manfaat dari perkembangan era globalisasi. Dalam konteks tersebut, daya saing harus dipandang sebagai kemampuan untuk mengoptimalkan sumber daya yang dapat melindungi kepentingan negara, keselamatan, keamanan, dan kesehatan warga negara serta perlindungan flora, fauna, dan pelestarian fungsi lingkungan hidup. Sedangkan dalam rangka memajukan kesejahteraan umum, daya saing harus dipandang sebagai kemampuan mengoptimalkan sumber daya dalam memanfaatkan pasar global sebagai sarana peningkatan kemampuan ekonomi bangsa Indonesia."

65 Standardisasi adalah proses merencanakan, merumuskan, menetapkan, menerapkan, memberlakukan, memelihara, dan mengawasi Standar yang dilaksanakan secara tertib dan bekerja sama dengan semua Pemangku Kepentingan (Pasal 1 Angka 1 Undang-Undang Nomor 20 Tahun 2014 tentang Standarnisasi dan Penilaian Kesesuaian/UU SPK). Penilaian Kesesuaian adalah kegiatan untuk menilai bahwa barang, jasa, sistem, proses, atau personal telah memenuhi persyaratan acuan (Pasal 1 Angka 2 UU SPK). Standar adalah persyaratan teknis atau sesuatu yang dibakukan, termasuk tata cara dan metode yang disusun berdasarkan konsensus semua pihak/pemerintah/keputusan internasional yang terkait dengan memperhatikan syarat keselamatan, keamanan, kesehatan, lingkungan hidup, perkembangan ilmu pengetahuan dan teknologi, pengalaman, serta perkembangan masa kini dan masa depan untuk memperoleh manfaat yang sebesarbesarnya. (Pasal 1 Angka 3 UU SPK). 
Di bidang hukum kekayaan intelektual pasca MEA berlaku, telah dilakukan pembangunan hukum berupa pembaruan hukum yaitu revisi terhadap UndangUndang Nomor 14 Tahun 2001 tentang Paten menjadi Undang-Undang Nomor 13 Tahun 2016 tentang Paten (UU Paten) dan Undang-Undang Nomor 15 Tahun 2001 tentang Merek menjadi Undang-Undang Nomor 20 Tahun 2016 tentang Merek dan Indikasi Geografis (UU Merek dan IG). Penjelasan umum UU Paten mengatakan:

"Peranan teknologi menjadi perhatian utama di negara-negara maju dalam menjawab permasalahan pembangunan bangsa dan meningkatkan pertumbuhan ekonomi. Di berbagai negara maju, kebijakan ekonomi dan kebijakan teknologi semakin terintegrasi dan diselaraskan untuk meningkatkan daya saing nasional. Dengan demikian, salah satu kebijakan diarahkan kepada meningkatkan pendayagunaan teknologi dalam sektor produksi untuk peningkatan perekonomian nasional dan penghargaan terhadap teknologi dalam negeri."

UU Paten memberikan arahan bahwa produk atau proses teknologi yang dihasilkan oleh UMKM mendapat perlindungan hukum, sehingga pihak lain tidak dapat menggunakan tanpa izin pemegang paten atau apabila meminta izin (lisensi), maka pemegang paten berhak atas hak ekonomi (royalti). Selain itu, kreasi tersebut akan memberikan nilai tambah terhadap produk (barang atau jasa) atau proses yang diberikan paten sehingga akan meningkatkan daya saing karena memiliki nilai jual yang lebih tinggi.

Selanjutnya, bagian Menimbang UU Merek dan IG berbunyi:

“a. di dalam era perdagangan global, sejalan dengan konvensi internasional yang telah diratifikasi Indonesia, peranan Merek dan Indikasi Geografis menjadi sangat penting terutama dalam menjaga persaingan usaha yang sehat, berkeadilan, pelindungan konsumen, serta pelindungan UMKM dan industri dalam negeri;

b. bahwa untuk lebih meningkatkan pelayanan dan memberikan kepastian hukum bagi dunia industri, perdagangan, dan investasi dalam menghadapi perkembangan perekonomian lokal, nasional, regional, dan internasional serta perkembangan teknologi informasi dan komunikasi, perlu didukung oleh suatu peraturan perundangundangan di bidang Merek dan Indikasi Geografis yang lebih memadai."

Berdasarkan UU tersebut secara tegas disebutkan merek dan IG penting dalam melindungi UMKM untuk memberikan kepastian hukum bagi perdagangan dan investasi baik nasional maupun regional (MEA). Dengan demikian, produk barang atau jasa UMKM yang dilindungi UU Merek dan IG akan mempunyai daya saing dibandingkan dengan produk yang tidak bermerek karena salah satu fungsi merek adalah jaminan kualitas dan reputasi. Selanjutnya, IG menunjukan asal daerah atau 
tempat produk tersebut dihasilkan dan memiliki kualitas tertentu, sehingga penunjukan daerah tertentu, misalnya produk buatan UMKM Tasikmalaya berkaitan erat dengan peningkatan daya saing bagi UMKM daerah yang bersangkutan, karena produknya selain berkualitas juga akan lebih mudah dikenal oleh konsumen lokal, nasional atau regional.

Sebelum MEA berlaku, dalam rangka peningkatan daya saing nasional Indonesia telah mempersiapkan diri untuk menghadapi integrasi ekonomi regional tersebut yaitu dikeluarkannya Keputusan Presiden Republik Indonesia Nomor 37 Tahun 2014 tentang Komite Nasional Persiapan Pelaksanaan Masyarakat Ekonomi Association of South East Asian Nations (Keppres 37/2014) dan Instruksi Presiden Republik Indonesia Nomor 6 Tahun 2014 tentang Peningkatan Daya Saing Nasional Dalam Rangka Menghadapi Masyarakat Ekonomi Association of South East Asian Nations (Inpres 6/2014).

Komite Nasional sebagaimana dimaksud dalam Keppres 37/2014 mempunyai tugas sebagai berikut: a) mengoordinasikan persiapan pelaksanaan MEA; b) mengoordinasikan percepatan peningkatan daya saing nasional dalam rangka pelaksanaan MEA; c) mengambil langkah-langkah penyelesaian hambatan dan permasalahan dalam persiapan dan pelaksanaan MEA serta peningkatan daya saing nasional; dan d) mengoordinasikan pelaksanaan sosialisasi kepada seluruh pemangku kepentingan (stakeholder) terhadap persiapan dan pelaksanaan MEA serta peningkatan daya saing nasional. ${ }^{66}$ Sedangkan Inpres 6/2014 pada intinya mengambil langkah-langkah yang diperlukan sesuai dengan tugas, fungsi, dan kewenangan masing-masing pejabat yang ditunjuk untuk secara terkoordinasi dan terintegrasi melakukan peningkatan daya saing nasional dan melakukan persiapan pelaksanaan MEA serta pelaksanaan peningkatan daya saing nasional dan persiapan pelaksanaan MEA dengan strategi yang telah ditentukan dalam Inpres tersebut.

Kebijakan pemerintah untuk melakukan persiapan dan pelaksanaan sebelum dan pasca berlakunya MEA 2015, pada dasarnya untuk memajukan kesejahteraan umum sebagaimana konsep Teori Negara Kesejahteraan. Implementasi kebijakan tersebut melalui pembangunan hukum (pembaruan hukum atau pembentukan hukum secara terus menerus dan berkesinambungan) sebagai sarana perubahan masyarakat dalam arti hukum berperan dalam pembangunan agar dapat berjalan dengan tertib seperti yang dikemukakan oleh teori hukum pembangunan. Selanjutnya, substansi pembangunan hukum diarahkan untuk peningkatan daya saing terutama bagi UMKM perlu memperhatikan faktor-faktor penentu daya saing dengan memperhatikan keunggulan kompetitif yang dimiliki Indonesia dan Teori

66 Pasal 2 Keputusan Presiden Republik Indonesia Nomor 37 Tahun 2014 tentang Komite Nasional Persiapan Pelaksanaan Masyarakat Ekonomi Association of South East Asian Nations. 
Daya Saing Model Sembilan Faktor yang dikemukakan oleh Dong-Sung Cho untuk melengkapi Teori Daya Saing Model Diamond Michael Porter agar dapat menjawab peningkatan daya saing internasional di negara-negara berkembang, seperti Indonesia.

Berdasarkan Teori Daya Saing Model Sembilan Faktor, Indonesia mempunyai keunggulan kompetitif, yaitu sumber daya alam berlimpah, lingkungan bisnis cukup kondusif untuk pemasaran barang dan jasa, industri terkait dan pendukung meskipun belum lengkap tetapi sudah tersedia, serta permintaan domestik dapat diharapkan dengan penduduk terbanyak ke-4 dunia. Selanjutnya tenaga kerja kerja banyak dan mempunyai potensi tetapi memang perlu dididik agar berkompeten di bidangnya, politisi dan birokrat memang harus diakui masih perlu dibenahi, para wirausahawan (termasuk UMKM) mempunyai harapan untuk berkembang melalui pemberdayaan, manajer, dan insinyur yang profesional cukup memadai. Sedangkan peristiwa peluang eksternal juga mempunyai posisi strategis karena Indonesia berada di antara dua benua, dan telah menjalin kerja sama dengan negara-negara ASEAN dan negara maju lainnya, meratifikasi konvensi terkait peningkatan daya saing. Dengan demikian, apabila dikaji menurut Teori Daya Saing Model Sembilan Faktor (meskipun masih ada hambatan dan kendala) dilengkapi dengan kebijakan di bidang perundang-undangan yaitu pembangunan hukum, maka Indonesia mempunyai potensi untuk menjadi negara yang memiliki daya saing tinggi dibandingkan dengan negara-negara ASEAN lainnya, sehingga tujuan nasional untuk memajukan kesejahteraan umum sebagaimana konsep negara kesejahteraan dapat tercapai.

\section{Penutup}

Pembangunan hukum untuk peningkatan daya saing UMKM telah dilakukan sebelum dan pasca berlakunya MEA 2015 melalui beberapa peraturan perundangundangan baik pembaruan hukum maupun pembentukan hukum baru. Namun pembangunan hukum tersebut masih perlu dilakukan terus menerus secara berkesinambungan karena upaya peningkatan daya saing UMKM mempunyai akibat yang luas terhadap bidang-bidang lainnya, sehingga memerlukan harmonisasi dan sinkronisasi baik di antara perundang-undangan terkait lainnya, maupun dalam rangka pelaksanaan MEA 2015, namun dengan tetap memperhatikan kepentingan nasional. Pembangunan hukum perlu dilakukan secara simultan pasca berlakunya MEA 2015 adalah di bidang UMKM (seperti pangan, pertanian, penanaman modal, ekspor impor), lembaga pembiayaan ketenagakerjaan, persaingan usaha, serta bidang perpajakan. 


\section{Daftar Pustaka}

\section{Buku}

Ibrahim R, Prospek BUMN dan Kepentingan Umum, PT Citra Aditya Bakti, Bandung, 1997.

Lili Rasjidi dan Ira Rasjidi, Dasar-dasar Filsafat dan Teori Hukum, PT Citra Aditya Bakti, Bandung, 2001.

Mochtar Kusumaatmadja, Hukum, Masyarakat dan Pembinaan Hukum Nasional, Bina Cipta, Jakarta, 1976.

Bandung, 2002.

Mulyana W. Kusumah, Peranan dan Pendayagunaan Hukum dalam Pembangunan, Alumni, Bandung, 1982.

Nopirin, Ekonomi Internasional, BPFE, Yogyakarta, 2012.

R. Hendra Halwani, Ekonomi Internasional dan Globalisasi Ekonomi, Edisi Kedua, Ghalia Indonesia, Bogor, 2005.

Satjipto Rahardjo, Pemanfaatan IImu-IImu Sosial bagi Pengembangan Studi Hukum, Cetakan ke-1, Alumni, Bandung, 1977.

Sudjana, Perlindungan Desain Tata Letak Sirkuit Terpadu, Widya Padjadjaran, Bandung, 2011.

Sumantoro, Hukum Ekonomi, UI Press, Jakarta, 1986.

\section{Dokumen Lain}

Akhmad Aulawi, "Arah Pembangunan Hukum Dalam Menghadapi ASEAN Economic Community 2015", Jurnal Rechtvinding, Badan Pembinaan Hukum Nasional (BPHN), http://rechtsvinding.bphn.go.id/view/view online.php?id=21.diakses 25 Januari 2017

Akhmad Farhan, "Perbandingan Daya Saing Indonesia Diantara Negara-Negara ASEAN", https://www.researchgate.net/publication/295073891 Perbandingan Daya Saing Indonesia Diantara Negara-Negara ASEAN, diakses 5 Januari 2017.

Amrina Rosyada, “Undang-Undang Nomor 7 Tahun 2014: Bentuk Strategi atau Bentuk Ketidakpercayaan Diri dalam Menghadapi ASEAN Economic Community 2015?", https://ideasforaec.wordpress.com/2015/10/18/undang-undangnomor-7-tahun-2014-bentuk-strategi-atau-bentuk-ketidakpercayaan-diridalam-menghadapi-asean-economic-community-2015/, diakses 21 Januari 2017.

Association of South-East Asian Nations, "ASEAN Economic Community (AEC)", http://www.asean.org/storage/2012/05/56.-December-2015-Fact-Sheet-onASEAN-Economic-Community-AEC-1.pdf, diakses 18 Januari 2014. 
Joko Tri Haryanto, "Kualitas Belanja, Kinerja, dan Daya Saing Indonesia", http://www.kemenkeu.go.id/en/node/43572, diakses 7 Januari 2017.

Kacung Abdullah, "Kesiapan Industri Kecil Menengah dalam Rangka Menyongsong Masyarakat Ekonomi ASEAN (MEA) 2015", Presentasi disampaikan oleh Dirjen IKM pada acara launching Aplikasi International Trade and Investment Summit 2015 di Jakarta, 28 Agustus 2014, https://www.slideshare.net/abdul300483/ kesiapan-ikm-menghadapi-mea-2015, diakses 20 Januari 2017.

Komar Kantaamadja, "Peran dan Fungsi Profesi Hukum dalam Undang-undang Perpajakan", Makalah dalam Seminar Nasional Hukum Pajak IMNO-UNPAD, Juli 1985.

Masnur Tiurmaida Malau, “Aspek Hukum Peraturan dan Kebijakan Pemerintah Indonesia dalam menghadapi Liberalisasi Ekonomi Regional: Masyarakat Ekonomi Asean 2015", Jurnal Rechtvinding, Vol. 3, No. 2, Agustus 2014, BPHN, http://rechtsvinding.bphn.go.id/view/?id=170 diakses 27 Januri 2017

Purnama Kusumaastuti, Ega Maharani Asih, Carmidah, "Strategi dan LangkahLagkah UMKM dalam Menghadapi Masyarakat Ekonomi ASEAN (MEA) 2015", Journal \& Proceeding FEB Unsoed, Vol. 5, No. 1, 2015, http://jp.feb.unsoed.ac.id /index.php/sca-1/article/viewFile/641/pdf 84, diakses 19 Januari 2017.

Setyani Irmawati, "Strategi Peningkatan Daya Saing Industri Unggulan Provinsi Jawa Tengah untuk Menghadapi ASEAN Economic Community (AEC) 2015", Skripsi, Fakultas Ekonomi Universitas Negeri Semarang, 2015, http://lib.unnes.ac.id/22269/1/7111411053-s.pdf, diakses 17 Januari 2017.

Suci Ana Winta Ritonga, "Analisis Determinan Daya Saing Ekonomi Kabupaten Batu Bara", http://repository.usu.ac.id/bitstream/123456789/50293/3/ Chapter\%20II.pdf, diakses 15 Januari 2017.

Sunaryati Hartono, "Sejarah Perkembangan Hukum Nasional Indonesia Menuju Sistem Hukum Nasional", Makalah, 1991.

Vukovic, D., Jovanovic, A., dan Djukic, M, "Defining Competitiveness through the Theories of New Economic Geography and Regional Economy", Journal of the Geographical Institute Jovan Cvijic, SASA, 62(3), 2012.

Y. Sri Susilo, "Strategi Meningkatkan Daya Saing UMKM dalam Menghadapi Implementasi CAFTA dan MEA", Buletin Ekonomi, Vol. 8, No. 2, Agustus 2010.

\section{Dokumen Hukum}

Undang-Undang Nomor 17 Tahun 2007 tentang Rencana Pembangunan Jangka Panjang Nasional 2005-2025.

Undang-Undang Nomor 20 Tahun 2008 Tentang Usaha Mikro, Kecil, dan Menengah.

Undang-Undang Nomor 3 Tahun 2014 Tentang Perindustrian. 
Undang-Undang Nomor 7 Tahun 2014 Tentang Perdagangan.

Undang-Undang Nomor 20 Tahun 2014 tentang Standarnisasi dan Penilaian Kesesuaian

Undang-Undang Nomor 13 Tahun 2016 Tentang Paten.

Undang-Undang Nomor 20 Tahun 2016 Tentang Merek dan Indikasi Geografis.

Keputusan Presiden Republik Indonesia Nomor 37 Tahun 2014 Tentang Komite Nasional Persiapan Pelaksanaan Masyarakat Ekonomi Association of South East Asian Nations.

Instruksi Presiden Republik Indonesia Nomor 6 Tahun 2014 Tentang Peningkatan Daya Saing Nasional Dalam Rangka Menghadapi Masyarakat Ekonomi Association of South East Asian Nations). 